\title{
Pengaruh Media Audio Visual terhadap Kemampuan Menyimak Cerita Kelas V SD Negeri 68 Kota Bengkulu
}

Melza Ayuni Sari

Universitas Bengkulu

fansmelza@gmail.com

Daimun Hambali

Universitas Bengkulu

daimunhambali@gmail.com

\section{Resnani}

Universitas Bengkulu

resnani12@gmail.com

\begin{abstract}
This research aims to determine the effect of the use crossword puzzle media on the ability of vocabulary mastery of second grade students SDN 68 City of Bengkulu. This research is a quantitative research. The research method used is Quasi Experimental Design with The Matching Only Pretest-Posttest Control Group Design. The population in this study is all students of class II SDN in Bengkulu City that accredited A and use curriculum KTS. Sampling technique with Cluster Random Sampling. The sample obtained is SDN 68 Kota Bengkulu with the number of samples consisting of class $V A$ and $V B$. Data of this research are analyzed by using inferential analysis that is uji $t$. From the result of the research, the result of $t$ with thitung is 2,43 and $t$ tabel value with significant level $5 \%$ equal to 2,04. So with thitung $(2,43)>t t_{a b e l}(2,04)$. The calculated value obtained is greater than the value of tabel so that HO rejected and Ha accepted. The value of thitung obtained is greater than the tabel value then it can be concluded that there is influence of media use of audio visual to the ability to listen the story on the student of class $V$ in SDN 68 city of Bengkulu.
\end{abstract}

Keywords: Media, Audio visual, Listen, Story

\begin{abstract}
Abstrak
Penelitian ini bertujuan untuk mengetahui pengaruh penggunaan media teka-teki silang terhadap kemampuan penguasaan kosakata siswa kelas dua SDN 68 Kota Bengkulu. Penelitian ini adalah penelitian kuantitatif. Metode penelitian yang digunakan adalah Quasi Experimental Design dengan The Matching Only Pretest-Posttest Control Group Design. Populasi dalam penelitian ini adalah semua siswa kelas II SDN di Kota Bengkulu yang terakreditasi A dan menggunakan kurikulum KTS. Teknik pengambilan sampel dengan Cluster Random Sampling. Sampel
\end{abstract}


yang diperoleh adalah SDN 68 Kota Bengkulu dengan jumlah sampel terdiri dari kelas V A dan V B. Data penelitian ini dianalisis dengan menggunakan analisis inferensial yaitu uji t. Dari hasil penelitian, hasil $\mathrm{t}$ dengan thitung adalah 2,43 dan nilai t tabel dengan taraf signifikan 5\% sebesar 2,04. Begitu juga dengan thitung $(2,43)>$ ttabel $(2,04)$. Nilai hitung yang diperoleh lebih besar dari nilai ttabel sehingga HO ditolak dan Ha diterima. Nilai thitung yang diperoleh lebih besar dari nilai ttabel maka dapat disimpulkan bahwa ada pengaruh penggunaan media audio visual terhadap kemampuan mendengarkan cerita pada siswa kelas V di SDN 68 kota Bengkulu.

Kata kunci: Media, Audio visual, Dengar, Cerita

\section{Pendahuluan}

Bahasa Indonesia merupakan bahasa nasional negara Indonesia dalam berkomunikasi. Bahasa Indonesia juga merupakan salah satu mata pelajaran yang wajib diajarkan secara formal di setiap jenjang pendidikan di Indonesia. Pembelajaran Bahasa Indonesia di sekolah dasar bertujuan untuk terampil dalam berbahasa, yaitu terampil menyimak, berbicara, membaca, dan menulis. Hal ini sejalan dengan pendapat Saddhono (2014: 5) yang menyatakan bahwa" keterampilan berbahasa Indonesia yang mencakup : keterampilan menyimak (listening skills), keterampilan berbicara (speaking skills), keterampilan membaca (reading skills), dan keterampilan menulis (writing skills).

Sehubungan dengan pendapat di atas, Tarigan (2013: 2) keterampilan menyimak adalah sebagai dasar bagi keterampilan berbahasa lain. Hal ini dibuktikan oleh, Adler dalam Hermawan (2012: 30) mengubvngkapkan bahwa 53\% aktivitas komunikasi didominasi oleh menyimak, sedangkan menulis $14 \%$, berbicara $16 \%$ dan membaca $17 \%$. Berdasarkan kenyataan ini maka jelas kemampuan menyimak harus dibina dan ditingkatkan karena sangat penting dalam lingkungan pendidikan.

Pembelajaran menyimak masih kurang mendapat perhatian dan seringkali diremehkan. Selain itu, pembelajaran menyimak di Indonesia cukup memprihatinkan karena dianggap sebagai pembelajaran yang kurang penting dibandingkan dengan kemampuan berbahasa yang lain. Seperti yang diungkapkan oleh Field dalam Abidin (2012: 97), bahwa pembelajaran menyimak belum dianggap penting dan oleh karenanya banyak ditinggalkan para guru.

Selain itu, siswa cenderung kesulitan dalam pembelajaran menyimak, hal ini karena pembelajaran menyimak yang dilaksanakan guru kurang maksimal. Faktor penyebab kurang maksimalnya pelaksanaan pembelajaran menyimak, yaitu: (1) pembelajaran menyimak hanya dilakukan untuk menjawab pertanyaan tidak menggunakan media, (2) pembelajaran menyimak dilakukan sebagaimana layaknya pembelajaran membaca, (3) pengukuran kemampuan menyimak bersifat biasa, dan (4) pembelajaran menyimak tidak diarahkan pada pengembangan karakter siswa (Abidin, 2012: 98).

Dalam pembelajaran Bahasa Indonesia guru dapat memanfaatkan media yang ada. Misalnya, media animasi audio visual yang dapat dimanfaatkan untuk memberikan materi pembelajaran menyimak secara bervariasi. Dengan pemakaian media audio visual akan lebih menarik dibanding dengan media yang lain. Dalam media audio visual siswa dapat mengurangi kejenuhan siswa selama pembelajaran. Seorang guru harus mampu menciptakan pembelajaran dengan memberikan pengaruh berupa motivasi belajar dan pembelajaran yang menyenangkan. Maka, dengan media audio 
visual akan memperoleh tercapainya tujuan menyimak. Selain itu, siswa juga dapat melihat secara langsung sehingga membantu siswa dalam memahami materi dan informasi yang disampaikan.

Tanpa penggunaan media pembelajaran, siswa cepat merasa bosan. Sehingga dalam proses pembelajaran guru harus memfasilitasi siswa dengan memanfaatkan media pembelajaran yang menarik. Sebagaimana dijelaskan oleh Arsyad (2014: 29) yang mengatakan bahwa manfaat media pembelajaran dalam proses belajar-mengajar yaitu (a) media pembelajaran dapat memperjelas penyajian pesan dan informasi; (b) media pembelajaran dapat meningkatkan dan mengarahkan perhatian anak sehingga dapat menimbulkan motivasi belajar, interaksi yang lebih langsung antara siswa dan lingkungannya; (c) media pembelajaran dapat mengatasi keterbatasan indera, ruang dan waktu; dan (d) media pembelajaran dapat memberikan kesamaan pengalaman kepada siswa tentang peristiwa-peristiwa di lingkungan mereka, serta memungkinkan terjadinya interaksi langsung dengan guru, masyarakat, dan lingkungannya

Dengan kemajauan ilmu pengetahuan dan teknologi yang semakin pesat, membuat media pembelajaran terus berkembang sesuai dengan kondisi dan kebutuhan zaman. Berdasarkan Asyhar (2011: 44) media pembelajaran terdiri dari beberapa jenis, yaitu visual, audio, audio-visual, dan multimedia. Berdasarkan jenis-jenis media pembelajaran yang telah dikemukakan oleh Asyhar, maka peneliti akan menggunakan media audio visual berupa video.

Menurut Syaiful Bahri dan Aswan (2002: 141) "media audio visual mempunyai unsur suara dan unsur gambar ." Jenis media ini mempunyai kemampuan lebih baik karena mencakup dua aspek media sekaligus yaitu pendengaran dan pengelihatan. Dengan media audio visual siswa dapat melihat sekaligus mendengarkan sehingga siswa mendapat pengalaman langsung. Pengalaman itu dapat membuat pembelajaran lebih bermakna serta diharapkan dapat meningkatkan kemampuan siswa dalam mencari unsur instrinsik.

Ada pun penelitian yang terkait dengan penelitian ini dari hasil penelitian yang dilakukan oleh Gusmaidar (2016) bahwa beberapa siswa tidak serius mengikuti pembelajaran menyimak, tidak serius mengerjakan tugas dari guru serta memberi respon negatif terhadap keterampilan menyimak. Hal ini terjadi karena siswa menganggap pembelajaran menyimak kurang penting.

Dengan media teka teki silang anak dapat belajar sambil bermain, sehingga anak tertarik dan bersemangat dalam belajar. Siswa tidak hanya mendengar penjelasan yang disampaikan guru saja tetapi siswa dapat berperan langsung dengan objek yang dimainkan, sehingga pemahaman penguasaan kosakata bahasa Indonesia siswa akan terus bertambah. Berdasarkan uraian di atas, peneliti terdorong untuk melakukan penelitian dengan judul "Pengaruh Penggunaan Media Audio Visual terhadap Kemampuan menyimak pada siswa Kelas V SDN 68 Kota Bengkulu.”

\section{Metode}

Jenis penelitian ini menggunakan jenis penelitian kuantitatif, dengan metode eksperimen semu. Dalam metode eksperimen terdapat dua kelompok, yaitu kelompok eksperimen dan kelompok kontrol. Penelitian ini dilakukan untuk mengetahui pengaruh media pembelajaran yang digunakan terhadap kemmapuan menyimak cerita siswa, dimana akan diujikan pada kelompok yang berbeda. Kelompok yang pertama menjadi kelompok eksperimen, kegiatan pembelajaran menggunakan media audio visual berupa video. Sedangkan kelompok kedua menjadi 
kelompok kontrol, dalam proses pembelajarannya menggunakan pembelajaran konvensional dengan tidak menggunakan media. Desain penelitian yang digunakan yaitu The Matching only Pretest-Posttest Control Group Design. Untuk memperoleh kelompok yang benar-benar ekuivalen (setara), kelompok eksperimen dan kontrol disetarakan melalui pretest untuk melihat kemampuan awal siswa. Setelah diperoleh hasil yang homogen, selanjutnya dilakukan proses pembelajaran pada kedua kelompok dengan materi yang sama yaitu unsur-unsur instrinsik cerita.

Dalam penelitian ini, yang menjadi populasi yaitu seluruh siswa kelas V SDN Kota Bengkulu yang berakreditasi A menggunakan kurikulum KTSP di Kota Bengkulu berjumlah 10 sekolah dasar negeri yaitu, SDN 04, SDN 103, SDN 12, SDN 68, SDN 41, SDN 51, SDN 60, SDN 82, SDN 87, SDN 67. Teknik pengambilan sampel yang digunakan yaitu teknik cluster random sampling. Sampel adalah bagian dari jumlah dan karakteristik yang dimiliki oleh populasi tersebut (Sugiyono, 2017:81). Sependapat dengan Sugiyono, Ali,dkk (2014:227) mengemukakan bahwa sampel adalah pengumpulan data yang dilakukan hanya pada sebagian subyek yang mewakili populasi.

Hasil pengundian didapatkan sampel kelas V di Sekolah Dasar Negeri 68 Kota Bengkulu dan SDN 82 sebagai sampel uji coba instrumen. Kemudian dilakukan uji homogenitas, diperoleh data bahwa kelas kelas VB sebagai kelompok eksperimen yang berjumlah 32 siswa dan kelas VA berjumlah 31 siswa sebagai kelompok kontrol dan kelas VI D SDN 82 menjadi kelompok uji coba instrumen.

Instrumen yang digunakan dalam penelitian ini yaitu lembar tes, dimana tes yang digunakan berbentuk soal tes objektif terdiri dari 20 butir soal dengan 4 pilihan. Sebelum uji coba instrumen, terlebih dahulu dilakukan validasi ahli oleh Ibu Desi Andriani, M.TPd selaku guru kelas di SDN 1 Kota Bengkulu. Berdasarkan hasil validasi, diperoleh semua butir soal telah memenuhi persyaratan untuk digunakan sebagai instrumen penelitian dengan kategori baik.

Berdasarkan hasil uji coba instrumen, diperoleh 15 butir soal valid, reliabel dengan $\mathrm{r}_{11}=1,99$, taraf kesukaran yang bervariasi dan memiliki daya pembeda cukup, sednag, sukar. Dengan demikian dapat disimpulkan 12 butir soal layak digunakan. Peneliti hanya mengambil 10 butir soal sebagai soal pretest dan posttest pada kelas eksperimen dan kelas kontrol.

Teknik pengumpulan data yang digunakan pada penelitian ini yaitu dokumentasi berupa nilai hasil ulangan Bahasa Indonesia siswa semester I tahun ajaran 2017/2018 dan tes (pretest dan posttest. Dokumentasi nilai hasil ulangan siswa digunakan untuk menghitung uji homogenitas sampel. Data dokumentasi ini diperoleh dari wali kelas. Pretest dilaksanakan satu hari sebelum perlakuan diberikan. Masing-masing siswa diberikan lembar soal pretest. Setelah pretest dilaksanakan, kedua kelas diberikan perlakuan, dimana pada kelas eksperimen menggunakan media pembelajaran audio visual berupa video cerita sedangkan pada kelas kontrol menggunakan pembelajaran konvensional dan tidak menggunakan media. Setelah kegiatan pembelajaran usai, siswa diberikan soal posttest untuk mengetahui kemampuan yang diperoleh siswa setelah mengikuti proses pembelajaran.

Analisis data yang dilakukan meliputi analisis deskriptif yaitu penyajian data melalui tabel, perhitungan skor rata-rata (mean), dan varian; analisis uji prasyarat yaitu dengan melakukan uji normallitas dan uji homogenitas, dan analisis inferensial yaitu dengan uji-t. 


\section{Hasil}

Data hasil pretest menunjukkan pada kelompok eksperimen nilai tertinggi yaitu 80 , nilai terendah yaitu 40 dengan rata-rata 65,968. Standar deviasi 10,708, dengan varian 114,661. Pada kelompok kontrol nilai tertinggi yaitu 90, nilai terendah yaitu 50 dengan rata-rata 64,516 . Standar deviasi 10,576 dengan varian 111,858 . Data hasil posttest menunjukkan pada kelompok eksperimen nilai tertinggi yaitu 100, nilai terendah yaitu 60 dengan rata-rata 81,156. Standar deviasi 10,106, dengan varian 102,136. Pada kelompok kontrol nilai tertinggi yaitu 80, nilai terendah yaitu 30 dengan rata-rata 64,32. Standar deviasi 11,98, dengan varian 143,57.

Berdasarkan rata-rata pretest pada kelas eksperimen dan kelas kontrol, tidak terdapat perbedaan yang signifikan, artinya kemampuan awal yang dimiliki siswa pada kelompok eksperimen dan kelompok kontrol adalah sama. Sedangkan pada hasil posttest, terdapat perbedaan yang signifikan rata-rata pada kelompok eksperimen dan kelompok kontrol. Sebelum melakukan pengujian hipotesis menggunakan uji-t, peneliti melakukan uji prasyarat hipotesis yaitu uji normalitas dan uji homogenitas. Hal ini bertujuan agar data yang ingin diuji berdistribusi normal dengan varian yang homogen. Uji normalitas dan uji homogenitas yang peneliti lakukan yaitu data hasil pretest dan posttest siswa.

Berdasarkan uji normalitas hasil pretest dan posttest siswa, diperoleh hasil pretest maupun posttest pada kelompok eksperimen dan kelompok kontrol berdistribusi normal. Pada hasil pretest kelompok eksperimen diperoleh $\mathrm{X}^{2}$ hitung $=9,845$ dan pada kelompok kontrol $\mathrm{X}^{2}$ hitung $=6,855$, dengan $\mathrm{X}^{2}$ tabel $=11,070$. Pada hasil posttest kelompok eksperimen diperoleh $\mathrm{X}^{2} \mathrm{hitung}=5,744$ dan pada kelompok kontrol $\mathrm{X}^{2}$ hitung $=10,816$, dengan $\mathrm{X}^{2}$ tabel $=11,070$. Maka dapat disimpulkan data tersebut normal.

Berdasarkan uji homogenitas hasil pretest siswa, diperoleh $\mathrm{F}_{\text {hitung }}=1,02$ dengan $\mathrm{F}_{\text {tabel }}$ $=2$,52. Dari hasil perhitungan menunjukkan $\mathrm{F}_{\text {hitung }}<\mathrm{F}_{\text {tabel, }}$ maka dapat disimpulkan bahwa hasil pretest siswa pada kelompok eksperimen dan kelompok kontrol adalah homogen.Berdasarkan uji homogenitas hasil posttest siswa, Diperoleh $\mathrm{F}_{\text {hitung }}=1,31$ dengan $\mathrm{F}_{\text {tabel }}=2,52$. Dari hasil perhitungan menunjukkan $\mathrm{F}_{\text {hitung }}<\mathrm{F}_{\text {tabel, }}$ maka dapat disimpulkan bahwa hasil posttest siswa pada kelompok eksperimen dan kelompok kontrol adalah homogen. Setelah uji prasyarat hipotesis selesai dilakukan dengan hasil data normal dan homogen, maka peneliti melakukan uji hipotesis yaitu dengan uji $t$.

Berdasarkan hasil uji hipotesis (Uji-t) pretest siswa pada kelompok eksperimen dan kelompok kontrol diperoleh $t_{\text {hitung }}=0,06$, dengan $t_{\text {tabel }}=2,04$. Karena thitung $<t_{\text {tabel, }}$, maka tidak terdapat perbedaan hasil pretest antara kelompok eksperimen dan kelompok kontrol. Berdasarkan hasil uji hipotesis (Uji-t) posttest siswa pada kelompok eksperimen dan kelompok kontrol diperoleh thitung $=2,43$, dengan $t_{\text {tabel }}=$ 2,04. Karena thitung $>t_{\text {tabel, }}$ sehingga terdapat perbedaan hasil posttest antara kelompok eksperimen dan kelompok kontrol. Adapun rekapitulasi hasil penelitian dapat dilihat pada tabel 1 .

Tabel 1 Rekapitulasi Hasil Penelitian

Deskripsi Pretest

Posttest

Eksperimen

Kontrol

Eksperimen

Kontrol

Nilai Tertinggi

80

90

90

80

Nilai Terendah

40

50

40

30 


\begin{tabular}{|c|c|c|c|c|}
\hline Jumlah & 2111 & 2000 & 2597 & 2238 \\
\hline Rata-rata & 65,968 & 64,516 & 81,156 & 72,193 \\
\hline Standar Deviasi & 10,708 & 10,576 & 10,106 & 11,568 \\
\hline Varian & 114,661 & 111,858 & 102,136 & 133,837 \\
\hline \multicolumn{5}{|l|}{ Uji Normalitas } \\
\hline $\mathrm{X}^{2}$ hitung & 9,845 & 6,855 & 5,744 & 10,816 \\
\hline $\mathrm{X}^{2}$ tabel & 11,070 & 11,070 & 11,070 & 11,070 \\
\hline \multicolumn{5}{|l|}{ Uji Homogenitas } \\
\hline $\mathrm{F}_{\text {hitung }}$ & \multicolumn{2}{|c|}{1,02} & \multicolumn{2}{|c|}{1,31} \\
\hline $\mathrm{F}_{\text {tabel }}$ & \multicolumn{2}{|c|}{2,52} & \multicolumn{2}{|c|}{2,52} \\
\hline \multicolumn{5}{|l|}{ Uji Hipotesis } \\
\hline $\mathrm{t}$ hitung & \multicolumn{2}{|c|}{0,06} & \multicolumn{2}{|c|}{2,43} \\
\hline$t_{\text {tabel }}$ & \multicolumn{2}{|c|}{2,04} & \multicolumn{2}{|c|}{2,04} \\
\hline
\end{tabular}

\section{Pembahasan}

Tahap awal penelitian, yaitu dilaksanakan pretest pada kelompok eksperimen dan kelompok kontrol. Pretest dilaksanakan satu hari sebelum perlakuan diberikan. Berdasarkan hasil pretest tidak terdapat perbedaan yang signifikan kemampuan awal siswa pada kelompok eksperimen dan kelompok kontrol. Setelah pretest dilaksanakan, kedua kelompok diberikan perlakuan, dimana pada kelompok eksperimen menggunakan media pembelajaran audio visual sedangkan pada kelompok kontrol menggunakan pembelajaran konvensional dan tidak menggunakan media.

Pada kelompok eksperimen, proses pembelajaran dimulai dari kegiatan awal yaitu apersepsi, dengan melakukan tanya jawab yang berkaitan kegiatan sebelum tidur. Langkah kedua, guru mengajak siswa untuk menyimak cerita bersama sambil mengerjakan soal (pretest). Langkah ketiga, siswa dibagi perkelompok untuk berdiskusi mengenai unsur instrinsik video cerita yang guru tampilkan menggunakan LCD (peneliti). Kemudian, sebelum mengakhiri proses pembelajaran, peneliti membagikan lembar postest untuk dikerjakan oleh siswa. Pembelajaran di kelompok kontrol diawal pembelajaran hampir sama dengan yang dilakukan di kelompok eksperimen. kegiatan awal yaitu apersepsi, dengan melakukan tanya jawab yang berkaitan kegiatan sebelum tidur. Langkah kedua, guru mengajak siswa untuk menyimak cerita bersama sambil mengerjakan soal (pretest). Langkah ketiga, siswa dibagi perkelompok untuk berdiskusi mengenai unsur instrinsik yang di bacakan oleh guru (peneliti). Kemudian, sebelum mengakhiri proses pembelajaran, peneliti membagikan lembar postest untuk dikerjakan oleh siswa.

Dengan pembelajaran media permainan teka-teki silang siswa dapat memahami makna dan memperkaya kosakata bahasa Indonesia yang dimiliki siswa dengan cara yang menyenangkan melalui permainan. Seperti yang dikemukakan oleh Musfiqon (2012: 99) bahwa media pembelajaran permainan adalah sesuatu yang menyenangkan dan menghibur untuk dilakukan serta memungkinkan penerapan konsep-konsep yang akan memungkinkan proses pembelajaran jadi lebih efektif. Hal ini tentu sangat membantu siswa dalam memahami makna dari kosakata bahasa Indonesia pada siswa sekolah dasar kelas II yang pemikirannya masih dalam tahap operasional konkret, suatu yang realistis secara fisik. Hal ini sejalan dengan pendapat Desmita (2009 : 35) bahwa anak pada tahapan operasional konkret senang merasakan atau melakukan sesuatu secara langsung seperti halnya bermain, bergerak serta bekerja dalam kelompok. 
Penggunaan media audiovisual dalam penelitian ini memiliki dampak yang positif bagi siswa, dimana siswa dapat menyimak sesuatu secara langsung, sehingga siswa menjadi lebih aktif dan termotivasi untuk mengikuti kegiatan pembelajaran. Ketika diberikan media audiovisual pada kelompok eksperimen respon yang diberikan siswa sangat positif, hal ini terlihat dari antusias siswa dalam mengikuti kegiatan pembelajaran (lampiran 25 dan 26, gambar 2 dan 3 , Halaman 95). Hal ini sejalan dengan pendapat dengan Septiana Utaminingrum (2015: 119) menyatakan bahwa dengan menggunakan media pembelajaran audiovisual kemampuan menyimak cerita siswa menjadi lebih baik. Hal ini dapat dilihat dari hasil nilai postest siswa yang berpengaruh terhadap kemampuan menyimak cerita siswa.

Berdasarkan penelitian yang telah dilakukan, terlihat adanya perbedaan kegiatan pembelajaran yang berlangsung antara kelompok kontrol dengan kelompok eksperimen. Berbeda halnya dengan yang terjadi pada kelompok kontrol. Pada kelompok kontrol respon aktif dari siswa masih kurang ini terlihat dari suasana kelas yang kurang kondusif dan proses pembelajaran yang kurang efisien bila dibandingkan dengan kelompok eksperimen. Pada kelompok kontrol tidak diberikan perlakuan dengan pemberian media audiovisual, kelompok kontrol hanya dengan pembelajaran konvensional tanpa penggunaan media pembelajaran. Dalam proses pembelajaran, pada awal pembelajaran saja mereka tampak antusias, hal ini dikarenakan ada orang baru yang memberikan pembelajaran. Berjalan beberapa menit kemudian, sebagian siswa tampak ada yang bosan dan mulai tidak menyimak dengan baik.

Peran media media audio visual dalam membantu siswa dalam kemampuan menyimak cerita sangat diperlukan. Hal ini dikarena media media audio visual dapat membantu guru dalam memperjelas cerita yang disampaikan yang bersifat abstrak. Secara keseluruhan berdasarkan hasil penelitian ini, media audiovisual berpengaruh terhadap kemampuan menyimak cerita siswa pada kelas V di SDN 68 Kota Bengkulu.

\section{Simpulan}

Berdasarkan data hasil penelitian, pengolahan data dan pembahasan, maka dapat disimpulkan bahwa terdapat pengaruh media audio visual terhadap kemampuan menyimak cerita pada siswa kelas V SDN 68 Kota Bengkulu. Hal tersebut dapat dilihat dari perbedaan antara hasil postest kelompok eksperimen dan kelompok kontrol. Perbedaan dapat dibuktikan dari hasil kemampua menyimak cerita siswa pada $\mathrm{V}$ pada uji t posttest, thitung lebih kecil dari ttabel. Dengan nilai thitung $(2,43)>t_{\text {tabel }}$ $(2,04)$ pada taraf signifikan $5 \%$, dapat disimpulkan bahwa thitung lebih besar dari pada $t_{\text {tabel, }}$ dan artinya $\mathrm{H}_{\mathrm{a}}$ diterima dan terdapat perbedaan.

\section{Saran}

Berdasarkan hasil penelitian yang dilakukan, maka disarankan bagi peneliti lain yang ingin menindaklanjuti penelitian ini di sarankan bahwa dalam pembelajaran menyimak cerita menggunakan media auido visual / dibutuhkan video yang jelas agar lebih jelas dan mudah untuk disimak.

\section{Referensi}

Musfiroh, T. 2010. Cerita untuk Perkembangan Anak. Golo Umbulharjo. Yogyakarta, PT Navila. 
Musfiqun. 2012. Pengembangan media dan sumber pembelajara. Jakarta. PT. Prestasi Pustaka Publisher.

Septianing, U. 2010. Pengaruh Media audio visual dalam Pembelajaran Bahasa Indonesia pada keterampilan Menyimak Cerita Siswa kelas V SD di Kecamatan Pandak Bantul Daerah Istimewa Yogyakarta, Skripsi, Yogyakarta, FIP UNY.

Sugiyono. 2014. Metode Penelitian Pendekatan Kuantitatif Kualitatif dan R\&D. Bandung: Alfabeta.

Sugiyono. 2016. Metode Penelitian Kuantitatif, Kualitatif dan R\&D. Bandung: Alfabeta.

Sugiyono. 2017. Metode Penelitian Pendidikan (Pendekatan Kuantitatif, kualitatif, dan $R \& D$ ). Bandung: Alfabeta.

Tarigan. 2013. Menyimak sebagai suatu keterampilan berbahasa. Bandung, CV Angkasa

Tarigan. H., G. 2008. Menyimak Sebagai Suatu keterampilan Berbahasa. Bandung: Angkasa.

Winarni, E., W. 2011. Penelitian Pendidikan. Bengkulu: FKIP UNIB.

2011. Bahan Ajar Statistik. Bengkulu: FKIP UNIB. 